\title{
Investigating the Influence of Social Class on Consumers' Shopping Behaviour in Nigeria
}

\author{
Okonkwo Deborah Chinwendu Ph.D \\ Lecturer \\ Department of Marketing \\ University of Nigeria, Enugu Campus \\ Nigeria \\ Email: chinwendu.okonkwo@unn.edu.ng \\ Moguluwa Chinwuba Shedrack Ph.D \\ Associate Professor \\ Department of Marketing \\ University of Nigeria Enugu Campus \\ Nigeria \\ Email: shedrack.moguluwa@unn.edu.ng
}

Received: December 2, 2018

Accepted: December 20, 2018

Online Published: December 25, 2018

\begin{abstract}
Purpose - This research is a critical effort towards investigating the shopping behaviour of consumers among different social class categories in Nigeria. The purpose of this paper is to evaluate the underlying factors influencing consumers' shopping behaviour in order to establish if there is really a clear-cut distinction in this regard among the various social class categories.

Design/methodology/approach - This study adopted the cross-sectional research approach and the survey research method. This study was carried out in order to determine whether there is a significant influence of social class on consumers' choice of shopping outlet; and investigate the extent to which social class significantly influenced consumers' organization of purchases, shopping style, and shopping pattern in Nigeria. A total of 384 copies of the questionnaire were distributed to individuals within Enugu metropolis, however only 350 copies were considered usable for data analysis. Respondents were selected using the convenience sampling technique. Descriptive statistical methods such as frequencies and percentages were used in data presentation. The chi-square and multiple regression statistics were used to analyse data.

Findings - The results indicate that social class significantly influenced consumers' choice of shopping outlet; social class did not in any way significantly influence consumers' organization of purchases; occupation/profession did not have a significant influence on consumers' behaviour with respect to their shopping style; and income and occupation/profession did not have a significant influence on consumers' behaviour with respect to their shopping pattern.

Practical implications - This paper presents a spotlight on Nigerian consumers' shopping pattern vis-à-vis the age long social class theory. It revisits the significance of the concept of social class to marketing practice with a strong emphasis on consumer behaviour.

Originality/Value - The significance of this paper is apparent in its proven application of the age-long social class concept in understanding consumer behaviour patterns in these contemporary times. As such, it requires a re-visit by marketing scholars so as to bring it back to limelight considering its relevance to consumer behaviourial patterns.
\end{abstract}

Keywords: Social Class, Consumer Behaviour, Shopping, Income, Occupation, Education 


\section{Introduction}

The Nigerian retail industry has developed significantly over the years, changing gradually from traditional to more modern systems; such that from buying and selling at open air markets in both urban and rural areas, Nigerians are increasingly patronizing convenience stores, supermarkets and online shops (Philips Consulting Limited, 2014). Since the introduction of the concept of social class into the marketing literature, it has been an interesting aspect of study for marketing scholars and practitioners (Mihic \& Culina, 2006). The decision consumers make with respect to acquisition of products is of special interest, especially as it relates to the social class category to which a person belongs. It is very important to note that social class as a context is rooted both in an individual's substance of social life such as wealth, education, work and also individuals' material resources as well as perceptions of rank in relation to others in society, with a proportionate influence on behaviour (Kraus, Piff, \& Mendoza-Denton, 2012).

According to Steven (2013), global integration is transforming economies throughout the world, thereby making decisions of consumers more increasingly complex. He observed that consumers in less developed countries used to have a restricted choice in the retail environment going by the closed nature of their marketing systems. However, with globalization operating alongside reformed economic policies, these consumers now experience a more modern market place, and now enjoy all that it has to offer. In developing countries like Nigeria, consumers make decisions as to whether to shop in traditional open markets, supermarkets, departmental stores and the likes (Oghojafor, Ladipo \& Nwagwu, 2012). Yet, the choice that consumers make is determined by several factors such as technology, personality, demographics, e.t.c. However, Schiffman and Kanuk (2004) have argued that consumers' lifestyles have been greatly influenced by socio-economic status, thereby affecting their shopping styles. In actual fact, consumers' shopping behaviour reflects a set of attitudes that characterizes the patterns of consumers' choices (Dawson, Findley \& Sparks, 2006) some of which are as a result of socio-cultural factors.

The literature shows that consumers' shopping (purchasing) behaviour have been studied from several perspectives which includes frequency and rate of purchases of certain products (Mihic \& Culina, 2006; Ohen et.al, 2004; Wood, 1998); quality of products purchased (Alooma \& Lawan, 2013; Lawan \& Zanna, 2013); and choice of shopping outlets and shopping styles (Basil et.al 2014; Durmaz et.al, 2011). This study falls under the latter category. It focuses on consumers' shopping behaviour as it relates to their choice of shopping outlets, shopping organization, shopping arrangement and shopping style, considering their social class category.

\section{Statement of the Problem}

The consumer decision making process reveals a series of stages that individuals undergo as they make purchase decisions. From the very first stage of identifying a problem i.e. an existing need, to the point of evaluating alternatives, psychological influences are evident; however, the stage where customers initiate a purchase action captures the consumer's actual behaviour, which is definitely a function of the preceding phases. Consumer's behaviour which involves how they acquire products reveals very striking differences with respect to shopping styles and purchase patterns existing among different consumer categories. The existence of social class raises issues as to whether all consumers shop alike in reality. In actual fact, different shopping styles exist; and consumer decision making is not only concerned about product and brand features but also on other criteria such as choice of retail outlets (Jobber, 2009). So, it becomes necessary to investigate whether social class actually determines a consumers' shopping behaviour, as these criteria such as outlet of shopping now constitutes an important choice set for today's modern customer (Oghojafor \& Nwagwu, 2013).

The literature reveals divergent views on this subject matter. While some assert that people within the same social class exhibit a very high similarity in attitudes such as living in similar neighbourhoods, dressing alike and shopping at the same type of stores; others argue that influence of social class on individuals is not really as enduring as it is projected, but is rather a relatively superficial concept that has only little impact upon the psychology of an individual and can be overcome with sufficient deliberate efforts (Kingston, 2000). The truism of this opinion is what this study is set out to investigate. It is therefore, based on this premise that this study seeks to investigate critically into the shopping behaviour (style) of consumers from various social classes in Nigeria. Specifically, with the existence of different shopping options available to the present Nigerian consumers such as online shopping, instore shopping (departmental stores, multiple chain stores, convenience stores), open-air markets, roadside kiosks and shops; this study seeks to critically examine the various shopping styles, organizations and patterns among different consumer categories in a bid to discover the influence of social class peculiarities on their choices.

\section{Research Objectives}

The purpose of this study is to investigate into the shopping behaviour of consumers among different social class categories in Nigeria. However, the specific objectives are to:

- Determine whether social class significantly influences consumers' choice of shopping outlet in Nigeria

- Examine the extent of influence of social class on consumers' organization of purchases in Nigeria 
- Ascertain the extent of influence of social class on consumers' shopping style in Nigeria

- Evaluate the extent of influence of social class on consumers' shopping pattern in Nigeria

4. Research Hypotheses

$\mathrm{H}_{1}$ : There is no significant influence of social class on consumers' choice of shopping outlet in Nigeria

$\mathrm{H}_{2}$ : Social class does not significantly influence consumers' organization of purchases to a large extent in Nigeria

$\mathrm{H}_{3}$ : Social class does not significantly influence consumers' shopping style to a large extent in Nigeria

$\mathrm{H}_{4}$ : Social class does not significantly influence consumers' shopping pattern to a large extent in Nigeria

5. Research Questions

- How does social class significantly influence consumers' choice of shopping outlet in Nigeria?

- To what extent does social class significantly influence consumers' organization of purchases in Nigeria?

- To what extent does social class significantly influence consumers' shopping style in Nigeria?

- To what extent does social class significantly influence consumers' shopping pattern in Nigeria?

6. Literature Review

6.1 Conceptual Framework

6.1.1 Social Class

Social class refers to a 'relatively homogenous and enduring divisions in a society, hierarchically ordered and with members who share similar values, interests and behaviour'. It is also the division of members of a society into a hierarchy of distinct status classes, so that members of each class have either higher or lower status than members of other classes. (Kotler \& Keller, 2012; Schiffman, Kanuk \& Das, 2006). Consequently, social class is believed to have certain features such as similarity in behaviour of members in structure, education levels, attitudes and communication styles, income, values, place of living; and possibility of transition from one social class to another (Allen, 2002; Gherasim, 2013; Williams, 2002). More succinctly, social class is shaped by an individual's material resources as well as perceptions of rank vis-à-vis others in society (Kraus, Piff \& Mendoza-Denton, 2012).

6.1.2 Social Class Categories

There are several criteria for categorizing social class. These include: income, living area, education, wealth, family background etc (Allen, 2002). Kraus, Piff and Keltner (2011) specifically classify social class by three variables namely: Income, Education and Occupation. However, Boyce, Brown and Moore (2010) are of the opinion that an individual's judgment of these variables is formed by one's local frame of reference such as, the individuals to whom they compare their material wealth. This implies that more than one person within a similar wealth category might view themselves as belonging to different social classes depending on the individuals to whom they may be comparing their wealth status. Thus, apart from social class being a function of material resources, it is also based on an individual's own construction of social class rank in terms of others within the society (Cohen et.al, 2008).

Mihic and Gordana (2006) argue that some similarities in behaviour could still exist even among individuals or families from different social classes, thereby implying that social class is associated with values and lifestyles of consumers. In their own words, 'personal values and attitudes can have a greater influence to buyers' behaviour than the amount of income they have access to. The implication of this is that members of different social classes that have similar incomes can, depending on their values and preferences spend it on different contents and activities. In relation to values, one can talk about the significant consumers' segment whose income is not high enough to be considered wealthy by the contemporary society. However, in their desire to buy only the best, they buy less often and not as much, but they buy quality goods.'

Categories of social class vary depending on geographical and country characteristics. Kotler and Keller (2012) identified seven social class categories: lower-lowers, upper-lowers, working class, middle class, upper-middles, lower-uppers and upper-uppers. In Nigeria, the Philips Consulting Survey Report (2014) showed that the middleclass category earns between 75,000 to 100,000 per month. Consequently, the lower social class category would be those that earn less than 75,000 monthly and the upper social class category earns above 100,000 monthly.

6.1.3 Social Mobility

A notable phenomenon among social class is the possibility of movement from one category to another (Solomon, Bamossy, Askegaard \& Hogg, 2006). They identified three forms of social class mobility, namely: upward, downward and horizontal mobility. While upward mobility refers to an improvement in a person's position overtime that may lead to an increase in status, downward mobility is concerned with a decline in a person's status leading to an undesirable situation where a person's state of living reduces below previously accepted standards. However, horizontal mobility is simply a movement from one position to another still equivalent in social status

6.1.4 Measuring Social Class

In measuring social class, several subjective, reputational and objective measures (Schiffman, Kanuk \& Das, 2006) have been suggested. Under subjective measures, individuals are asked to estimate their own social class positions; 
under reputational measures, informants make judgments concerning the social class membership of others within the community; under objective measures, individuals answer specific socioeconomic questions and then are categorized according to their answers (Adler et.al, 2000; Kraus et.al, 2012; Mahalingam, 1998). The modality of this research falls within the last category.

6.1.5 Shopping (Buying) Behaviour

Consumer behaviour as an important concept in Marketing incorporates the totality of consumers' decisions in relation to the acquisition, consumption and disposition of products such as goods, services, time, ideas and experiences by human decision making units (Hoyer \& MacInnis, 2010). Consumer buying (shopping) behaviour is the actual decision of final consumers such as individuals and households who buy goods and services for personal consumption (Kotler \& Armstrong, 2008). This study focuses on the acquisition aspect of consumer behaviour. Generally, a product or service offering could be made available through different media. For instance, a piece of clothing could be bought from an open air market, a boutique, a show room, online etc. Individuals' decision regarding their choice of where to purchase certain products is greatly influenced by certain factors; and this study seeks to find out the extent to which social class significantly influences shopping behaviour. Usually, individuals directly or indirectly decide on where to acquire certain products. Similarly, in Nigeria, consumers have several shopping options which include modern retail stores, supermarket, open markets, seasonal markets, online, mobile markets etc (Oghojafor, Ladipo \& Nwagwu, 2012).

6.1.6 Traditional Shopping

Many Nigerians still prefer to shop through traditional retail channels such as open markets, super markets, street shops and malls (Philips Consulting Limited, 2014). Some of the reasons reported for this practice include the need for consumers to be certain about the product in terms of seeing, touching and trying the product before purchase, rather than rely on information from online retailers.

6.1.7 Online Shopping

The rapid development of technology giving rise to the pervasive influence of the internet has created a paradigm shift in the traditional way people shop. This shift is as a result of an explosive growth in the use of broadband technology combined with a change in consumer behaviour (Oppenheim \& Ward, 2006). This changing trend in consumers' shopping style has been attributed to the significant benefits it offers such as convenience and anytime/anywhere purchases (Joines et.al, 2003). Obviously, differences existing among social classes create a difference in shopping behaviour. Consequently, consumers from a higher social class generally purchase more and have a higher intention to purchase online because there is a higher probability that they possess a computer and have greater access to the internet (Smith \& Rupp, 2003). The reverse is the case for consumers from a lower social class as they may not possess the capacity to own and navigate a computer.

The framework for this study is as illustrated below:

\begin{tabular}{|c|c|}
\hline \multicolumn{1}{|c|}{ Social Class Parameters } & \multicolumn{1}{|c|}{ Shopping Behaviour } \\
\hline Educational Level & Choice of Shopping Outlet \\
Income & Organization of Purchases \\
Occupation & Shopping Style \\
& Shopping Pattern \\
\hline
\end{tabular}

Figure 1. An Illustration of the influence of social class parameters on consumers' shopping behavior

Source: Researchers' Conceptualization (2017)

\subsection{Review of Empirical Literature}

The significance of social class in understanding consumer purchasing behaviours has attracted substantial empirical studies as reflected in extant literature. Empirical studies revolving around consumers' shopping behaviour, especially in developing countries have been carried out along different dimensions, some of which are reviewed in this section. 
Mihic and Gordana (2006) studied the concepts of social class and income in respect to the degree of influence that each exerts over consumers' buying behaviour. With a study sample of 270 respondents within the two largest cities in Croatia, the various occupations, education and income level of consumers were captured. The results revealed that social class has greater influence over consumers' purchase and consumption behaviour of a greater range of products than income.

Durmaz, Celik and Oruc (2011) examined cultural factors and the impact they have on consumer buying behaviour. The study which involved the distribution of questionnaires to 1,286 respondents revealed that beliefs, culture and tradition are the most important factors influencing consumers' purchasing behaviour.

A cross-sectional survey was carried out by Oghojafor and Nwagwu (2013) where they focused on the socioeconomic variables influencing the store patronage behaviour of consumers in developing countries. The study surveyed a sample of 275 female respondents in Lagos state, Nigeria using multiple choice, closed-ended questionnaires. The results of the study showed that socio-economic variables such as income, educational attainment, type of employment, marital status and family size do not significantly influence shopping behaviour as regards store patronage of Nigerian women when shopping for grocery products. The study therefore suggested that these variables be de-emphasised by retailers when designing marketing strategies as it is unlikely to be a major factor for consideration.

Alooma and Lawan (2013) investigated a combination of demographic variables including income, occupation and education, and the effects they have on clothes buying behaviour of consumers in Borno state, Nigeria. Using a set of structured questionnaires duly filled and returned by 174 respondents, the results showed that these factors were highly significant in influencing consumers' buying behaviour. Therefore, they recommended that market segmentation be done on social class basis (specifically considering income) as this would further direct their marketing efforts towards yielding more effective results.

In examining the purchasing behaviour of some categories of consumers in Akwa-Ibom state, Nigeria towards some agricultural products, Ohen, Umeze and Inyang (2014) focused on some specific economic characteristics in a bid to discover how they influence consumers' choice and behaviour. The findings of the study showed that while income strongly influenced consumers' purchasing behaviour, educational level had no significant effect on consumers' purchase behaviour.

Similarly, Oghojafor and Nwagwu (2013) in another survey evaluated consumers' choice of shopping outlets in light of some socio-economic variables in Lagos state, Nigeria. By adopting a convenience sampling technique, respondents were chosen from the sampling frame, after which duly completed questionnaires were returned and analyzed. Interestingly, the results revealed that neither of the socio-economic variables such as income, level of education and type of employment actually influenced consumers' choice of shopping outlets in that area.

6.3 Summary and Gap in Literature

Given the nature of social class measurement especially with regards to the objective measures, there seems to be a dearth in literature on this subject matter in Eastern Nigeria. Most studies done on this subject have been carried out majorly in other areas such as the Western, Southern and Northern areas. This study is an attempt to bridge that gap as it is being carried out in Eastern Nigeria.

7. Research Methodology

The research design used in this study was purely descriptive, and data collection was by means of surveys. The sampling unit consisted of individuals within Enugu metropolis in Nigeria selected using the convenience sampling technique. The population of the study was 167,774 (NPC, 2010) and the sample size of 384 was derived statistically using the Cochran's formula (1963) for a known population. A set of well structured closed ended questionnaires was designed and used for data collection. The questionnaire was made up majorly of two sections, A and B. Section A contained questions that were directly related to the study while section B was meant to capture respondents' demographic profile. However, out of the total number of questionnaires distributed to respondents, only 350 copies of the questionnaires returned were used for analysis. Analysis was done using multiple regression and chi-square statistics with the aid of the Statistical Package for Social Sciences (SPSS).

8. Results

The multiple regression technique was used in this study to analyse data related to hypotheses 2,3 , and 4 as it allowed for different social class factors to be analysed separately but simultaneously so that the effect of each of them can be estimated on the dependent variable (shopping behaviour). The chi-square statistic was used to test hypothesis 1 as this was meant to only show a categorical relationship between the variables. 


\subsection{Demographic Characteristics of Respondents}

Table 1. Demographic characteristics of respondents

The table below shows the demographic characteristics of respondents used in this study.

\begin{tabular}{|c|c|c|c|}
\hline Demographic & Category & Frequency & Percent \\
\hline \multirow[t]{6}{*}{ Age } & 19 years and above & 62 & 17.7 \\
\hline & $20-35$ years & 225 & 64.3 \\
\hline & $36-50$ years & 46 & 13.1 \\
\hline & Over 50 years & 13 & 3.7 \\
\hline & Missing & 4 & 1.1 \\
\hline & Total & 350 & 100.0 \\
\hline \multirow[t]{4}{*}{ Gender } & Male & 122 & 34.9 \\
\hline & Female & 126 & 36.0 \\
\hline & Missing & 102 & 29.1 \\
\hline & Total & 350 & 100.0 \\
\hline \multirow[t]{14}{*}{ Occupation/Profession } & Unemployed & 38 & 10.9 \\
\hline & Students/Apprentice & 201 & 57.4 \\
\hline & Pensioners & 5 & 1.4 \\
\hline & Nanny/Housekeeper/Cook/Cleaner & 5 & 1.4 \\
\hline & Farmer & 4 & 1.1 \\
\hline & Self-employed semi-skilled & 30 & 8.6 \\
\hline & Private employees & 27 & 7.7 \\
\hline & Junior civil servants & 9 & 2.6 \\
\hline & Senior civil servants & 12 & 3.4 \\
\hline & Senior professionals & 4 & 1.1 \\
\hline & Business owners/administrators & 12 & 3.4 \\
\hline & Chief Executive Officers & 2 & 6 \\
\hline & Missing & 1 & 3 \\
\hline & Total & 350 & 100.0 \\
\hline \multirow[t]{8}{*}{ Highest Educational Qualification } & Uneducated & 5 & 1.4 \\
\hline & Primary school & 12 & 3.4 \\
\hline & Secondary School & 53 & 15.1 \\
\hline & Diploma/NCE & 44 & 12.6 \\
\hline & Graduate & 193 & 55.1 \\
\hline & Postgraduate & 36 & 10.3 \\
\hline & Missing & 7 & 2.0 \\
\hline & Total & 350 & 100.0 \\
\hline \multirow[t]{8}{*}{ Monthly Income } & Below N50,000 & 219 & 62.6 \\
\hline & $\mathrm{N} 51,000-\mathrm{N} 100,000$ & 66 & 18.9 \\
\hline & $\mathrm{N} 101,000-\mathrm{N} 200,000$ & 12 & 3.4 \\
\hline & $\mathrm{N} 201,000-350,000$ & 4 & 1.1 \\
\hline & $\mathrm{N} 351,000-\mathrm{N} 500,000$ & 5 & 1.4 \\
\hline & Above N500,000 & 5 & 1.4 \\
\hline & Missing & 39 & 11.1 \\
\hline & Total & 350 & 100.0 \\
\hline
\end{tabular}

From the table above, most of the respondents are young adults within the age range of 20 to 35 years of age while the older adults of 50 years and above responded least to the survey; more females than males responded to the survey although with a very slight difference; while most of the people surveyed are graduates, majority of the respondents earn income below N50,000 while fewer respondents earn above N350,000. 


\subsection{Test of Hypotheses}

\section{Hypothesis 1}

The result of the chi-square analysis shows that at $p<0.05$, there existed a significant relationship between consumers' shopping behaviour with respect to their choice of shopping outlet and the social class indicators namely educational level, occupation/profession and income. Therefore, social class significantly influenced consumers' choice of shopping outlet.

\section{Hypothesis 2}

The result of the analysis shows the t-values obtained and indicates how the dependent variable relates to the independent variables separately. The result shows that social class did not in any way significantly influence consumers' organization of purchases. This is because no significant t-values were obtained for any of the independent variables, as $p$ values for educational level, occupation and income were $0.577,0.893$, and 0.44 respectively, with corresponding t-values of $0.539,-0.135$, and 0.766 , all indicating $p$ values $>0.05$.

\section{Hypothesis 3}

The result shows that significant t-values were obtained for educational level and income at $p<0.05$. The t-values and significant values for these factors are 2.584, 0.01 and 2.002, 0.04 respectively. However, occupation/profession did not have a significant influence $(\mathrm{t}=0.265, p=0.79)$ on consumers' behaviour with respect to their shopping style.

\section{Hypothesis 4}

The result shows that only educational level has a significant influence on shopping behaviour with a t-value of 2.428 at 0.01 . However, $p$ values higher than 0.05 were obtained for occupation and income at $t=-0.066, p=0.94$, and $t=0.384, p=0.70$ respectively. Therefore, income and occupation/profession did not have a significant influence on consumers' behaviour with respect to their shopping pattern.

\section{Conclusion}

This study focused on investigating the influence of social class on consumers' shopping behaviour in Nigeria. The indices specifically used in this study for measuring social class include: educational level, income and occupation/profession; while choice of shopping outlet, organisation of purchases, shopping style and shopping pattern were used to operationalise shopping behaviour.

In Nigeria, consumers show a very strong link with respect to their choice of shopping outlet depending on the social class to which they belong (Alloma \& Lawan, 2013; Gherasim, 2013; Rani, 2014). While factors that determine the choice of shopping outlet for consumers within the higher social class category include the type of product involved, influence of family and friends, convenient opening and closing times and neatness of the environment; major factors considered by consumers within the lower social class category include availability of discounts and cheaper prices (Coleman, 1983).

It is however pertinent to state here that in many situations, social class influence on consumers' shopping behaviour actually varies. As is seen from this study, while some indicators of social class may have a strong influence on consumers' shopping behaviour, other indicators either do so to a little extent or not at all. In the case of consumers' organization of purchases, the influence of social class is not present at all (Oghojafor \& Nwagwu, 2013). In this study, organization of purchases was operationalised based on the strictness or flexibility exhibited during shopping. Specifically, consumers were grouped into categories of those who keep strictly to shopping list, those who shop intuitively without any shopping list, and those who actually make a shopping list but are very flexible in modifying the list depending on the market situation. This study implies that other factors outside social class are responsible for the way consumers organize their purchases. This affirms a previous study done by Steven (2013) which presents social class influence as being completely absent on consumers' shopping behaviour. In other words, flexibility of purchases (e.g. impulse buying) cuts across consumers from the various social class categories (Asuquo \& Igbongidi, 2015) and is not a practice of those within the lower social class groupings.

In terms of shopping style, individuals' income (Mihic \& Culina, 2006; Ohen, Umeze \& Inyang, 2014) and level of education exhibit a strong influence on consumers' behaviour; however, occupation/profession does not. This is consistent with findings of Meng and Fraedrich (2010) that emphasizes that the $21^{\mathrm{st}}$ century consumers in many situations seem to exhibit similarities to some extent in behaviour irrespective of their social class category. The shopping style delineated in this study are in terms of which category of customers are more likely to purchase high quality items inspite of the cost even if it means giving up the purchase of other items, and which of them would prefer purchasing good but cheaper items so that there could be means of purchasing other products. From this study, there is no clear cut demarcation of which consumers in the various social class categories actually belong to any of the two groups. However, it reveals that only a person's income and level of education irrespective of the social class to a great extent influences consumers' shopping style. 
In the same vein, a person's level of education (Alooma \& Lawan, 2013) strongly influences consumers' shopping pattern while income and occupation does not. The shopping patterns defined here are in terms of the extent to which shopping is either planned or unplanned. There does not seem to reflect the strong presence of social class on consumers' shopping pattern to a large extent. It only points out that shopping pattern are a function of how educated an individual is and not strictly an offshoot of a consumers' social class category.

10. Recommendations

This study is a progression of the seeming ongoing discourse as to the strict adherence of consumer behaviour to existing social class theories, which underscores the centrality of consumer behaviour in the Marketing field. While this study has focused on validating the existence of a relationship between these social class theoretical standpoints and consumer behaviour, it is strongly recommended that further studies be carried out to elucidate on how the constructs of social class actually affect consumer behaviour. It is expected that this would reinforce the argument and linkage supposedly present between the two concepts, and a way of redefining the continued significance of Social Class theories to modern day Marketing.

References

Adler, N; Epel, E; Castellazo, G and Ickovics, J (2000)."Relationship of subjective and objective social status with psychological and physiological functioning: Preliminary data in healthy, white women." Health Psychology, Vol 19, pp 586-592

Allen, D (2002). "Toward a theory of consumer choice as socio-historically shaped practical experience: The - fits like - a - glove framework." Journal of Consumer Research, Vol 28, pp 515-532

Alooma, A \& Lawan, A (2013). "Effects of consumer demographic variables on clothes buying behaviour in Borno State, Nigeria". International Journal of Basic and Applied Science, Vol 1( 4):791-799

Asuquo, E \& Igbongidi, P (2015). "Retail store merchandise assortment and display and their influence on consumer impulse buying behaviour in North-West, Nigeria. British Journal of Marketing Studies

Basil, G; Sunday, E; Anyadighibe, J \& Edward, J (2014). "An empirical study of the impact of non-store retailing on consumers' satisfaction in Calabar Metropolis." American International Journal of Contemporary Research, Vol 4 (12)

Bellenger, D \& Moschis, G (1982). “A socialization model of retail patronage.” Advances in Consumer Research, Vol 9, pp 373-378

Boyce, J; Brown, A \& Moore, S (2010). "Money and happiness: Rank of income, not income, affects life satisfaction." Psychological Science, Vol 21, pp 471-475

Cohen, S; Alper,C; Doyle, H; Adler, N; Treanor, J \& Turner, R (2008). "Objective and subjective socioeconomic status and susceptibility to the common cold." Health Psychology, Vol 27, pp 268-274

Coleman, R (1983). "The continuing significance of social class to marketing." Journal of Consumer Research, Vol $10(3)$

Dawson, J; Findlays, A \& Sparks, L (2006). The retailing leader. London: Routledge

Durmaz, Y; Celik, M \& Oruc, R (2011). "The impact of cultural factors on the consumer buying behaviours examined through an empirical study." International Journal of Business and Social Science, Vol 2(5), special issue

Gherasim, T (2013). "Behaviour social factors." Economy transdisciplinarity cognition, Vol 16, Issue 1, pp 5-14

Hoyer, D \& MacInnis, D (2010). Consumer behaviour, (5 ${ }^{\text {th }}$ edition). Ohio: South-Western Cengage Learning

Jobber, D (2009). Principles and practice of marketing. England: McGraw-Hill Publishing Company

Joiners, J; Scherer, C \& Scheufele, D (2003). "Exploring motivations for consumer web use and their implications for E-Commerce." Journal of Consumer Marketing, Vol 20(2):90-108

Kingston, W (2000). The classless society. Stanford: Stanford University Press

Kotler, P \& Armstrong, G (2008). Principles of marketing, pp 130. Upper Saddle River: Pearson Education Inc.

Kotler, P \& Keller, K (2012). Marketing management (14 $4^{\text {th }}$ edition). Edinburgh: Pearson Education Limited

Kraus, M; Piff, P \& Keltner, D (2011). "Social class, the sense of control, and social explanation." Journal of Personality and Social Psychology, Vol 97, pp 992-1004

Kraus, M; Piff, P \& Mendoza-Denton, R (2012). "Social class, solipsism, and contextualism: How the rich are different from the Poor." Psychological Review, Vol 119(3): pp 546-572

Lawan, A \& Zanna, R (2013). "Evaluation of socio-cultural factors influencing consumer buying behaviour of clothes in Borno State, Nigeria. International Journal of Basics and Applied Sciences, Vol 1(3): pp 519-529

Mahalingam, R (1998). "Essentialism, power and theories of caste: A developmental study." Dissertation Abstracts International, Vol 60, pp 2-13 
Meng, J \& Fraedrich, J (2010). " $21^{\text {st }}$ century social class theory as it applies to marketing." The marketing management Journal, Vol 20, Issue 1, pp 194-203

Mihic, M \& Culina, G (2006). "Buying behaviour and consumption: Social class versus income." Management, Vol 11(2):pp 77-92

Oghojafor, B \& Nwagwu, K (2013). "Choice of shopping outlets for grocery products and the socioeconomic profile of female consumers in Lagos, Nigeria." Journal of Sustainable Development Studies, Vol 4(2):88-113

Oghojafor, B; Ladipo, R \& Nwagwu, K (2012). "Outlets attributes as determinants of preference of women between a supermarket and a traditional open market." American Journal of Business and Management, Vol $1(4): 230-240$

Ohen, S; Umeze, G \& Inyang, E (2014). "Consumer purchasing behaviour for fruits and vegetables among civil servants in Essien Udim Local Government Area, Akwa-Ibom State, Nigeria." Food Science and Quality Management, Vol 23

Oppenheim, C \& Ward, L (2006). "Evaluation of websites for B2C E-Commerce." Aslib Proceedings: New Information Perspectives, Vol 58(3):237-260

Philips Consulting (2014). "Online shopping survey report - A study of current trends in online shopping in Nigeria." www.philipsconsulting.net

Rani, P (2014). "Factors influencing consumer behaviour." International Journal of Current Research Academic Review, Vol 2(9):52-61

Schiffman, Kanuk \& Das (2006). Consumer behaviour. Canada: Pearson Education Limited

Schiffman, L \& Kanuk, L (2004). Consumer behaviour, ( $8^{\text {th }}$ edition). Upper Saddle River: Pearson Prentice Hall

Smith, A \& Rupp, W (2003). "Strategic online customer decision making leveraging the transformational power of the internet." Online Information Review, Vol 2(6):418 - 432

Solomon, M; Bamossy, G; Askegaard, S \& Hogg, K (2006). Consumer behaviour: A European perspective, pp 438. Edinburgh: Pearson Education Limited

Steven, D (2013). "Consumer decision making styles in retailing: Evolution of mindsets and psychological impacts." Journal of Consumer Marketing, Vol 30, Issue 1, pp 75-87

Williams, G (2002). "Social class influences on purchase evaluation criteria." Journal of Consumer Marketing, Vol 19, $p$ p 249-276

Wood, M (1998). "Socio-economic status, delay of gratification, and impulse buying." Journal of Economic Psychology, Vol 19, pp 295-320

\section{Section A}

\section{Questionnaire}

1. Which of these do you consider most when deciding whether to buy a product or not?

Product price [ ] Quality [ ] Packaging [ ] Popularity of the product [ ] Discounts [ ]

2. Generally, how do you conclude over purchase price?

I just pay the amount as quoted by the seller even when there is an opportunity to bargain [ ]

I bargain price with the seller and pay the final agreed price [ ]

I do not bargain at all because I make most of my purchases from places where bargaining is not necessary

[ ]

3. Which of these describes your shopping pattern?

I usually plan my shopping activities so I do not go shopping anyhow [ ]

I do not plan my shopping so I go shopping whenever I feel there is need to [ ]

I go shopping only when items are getting finished or already finished [ ]

4. How do you organize your purchase activity?

I make a list of items I want to buy and keep strictly to it [ ]

I know the things I need so I just enter the market and begin to buy without making a list [ ]

I make a list of what I want to buy but can still modify it when I get to the market depending on the market situation [ ]

5. Which of these describes how you prefer to make purchases?

I prefer to purchase a single item that is of very high quality even if it is costly [ ]

I prefer to purchase an item of good quality that is relatively cheap so that I can still have money left to purchase other items [ ]

6. Now that the prices of most items have increased, in what way has your purchases been affected?

I still buy the same quantity I used to buy before [ ]

I have reduced the quantity I buy because of the increased cost of items [ ] 
I have switched to buying other brands that are quite cheaper [ ]

7. Where do you usually purchase the following items?

\begin{tabular}{|c|c|c|c|c|}
\hline & $\begin{array}{l}\text { Retail stores and } \\
\text { Supermarkets e.g. } \\
\text { Shoprite, Roban } \\
\text { stores,etc }\end{array}$ & $\begin{array}{l}\text { Open air markets Roadside shops } \\
\text { e.g. Ogbete, New } \\
\text { market, Artisan,etc }\end{array}$ & $\begin{array}{l}\text { Specialty shops-Fine } \\
\text { brothers, Albertina etc }\end{array}$ & NA \\
\hline \multicolumn{5}{|l|}{ Phones } \\
\hline \multicolumn{5}{|l|}{ Computer system } \\
\hline \multicolumn{5}{|l|}{$\begin{array}{l}\text { Accessories-chargers, batteries, } \\
\text { ear piece etc }\end{array}$} \\
\hline \multicolumn{5}{|l|}{ Electronics-Iron, TV, Radio } \\
\hline \multicolumn{5}{|l|}{ Books } \\
\hline \multicolumn{5}{|l|}{ Clothes } \\
\hline \multicolumn{5}{|l|}{ Shoes } \\
\hline \multicolumn{5}{|l|}{ Bags } \\
\hline \multicolumn{5}{|l|}{ Tissue } \\
\hline \multicolumn{5}{|l|}{ Clothes } \\
\hline \multicolumn{5}{|l|}{ Shoes } \\
\hline \multicolumn{5}{|l|}{ Washing detergent } \\
\hline \multicolumn{5}{|l|}{ Toothpaste } \\
\hline \multicolumn{5}{|l|}{ Plates and cutleries } \\
\hline \multicolumn{5}{|l|}{ Kitchen items-pot, cookers } \\
\hline \multicolumn{5}{|l|}{$\begin{array}{l}\text { Body care items -cream, } \\
\text { perfume, powder, bath soap, }\end{array}$} \\
\hline \multicolumn{5}{|l|}{ Fruits and vegetables } \\
\hline \multicolumn{5}{|l|}{ Foodstuffs - rice, beans, yams } \\
\hline \multicolumn{5}{|l|}{ Meat, fish } \\
\hline \multicolumn{5}{|l|}{ Food ingredients-maggi, salt, oil } \\
\hline \multicolumn{5}{|l|}{ Fresh tomatoes } \\
\hline $\begin{array}{l}\text { Snacks and confectionaries- } \\
\text { biscuits sweets }\end{array}$ & & & & \\
\hline
\end{tabular}

8. What do you consider most when deciding where to shop?

The type of product [ ] Where most of my friends/family/colleagues buy [ ] Convenient opening and closing times [ ] Closeness to where I live [ ] Neatness of the environment [ ] Availability of discounts [ ] Cheaper prices [ ]

9. Have you purchased any item online before? Yes [ ] No [ ]

10. Please, mark all the items that you have purchased online before? (Tick as many as are applicable) Books [ ] Electronics [ ] Kitchen wares [ ] Clothes [ ] Footwears [ ] Bags [ ] Mobile Phone [ ] Computer [ ] Personal care items [ ] Others [ ] Please specify

11. Have you ever experienced a change in standard of living before such as a change in income? Yes [ ] No [ ]

12. If yes, in what way did the change affect your lifestyle in making purchases?

I had to adjust my purchase volume to suit the change [ ]

Nothing actually changed. My purchase quantity still remained the same [ ]

13. In what way did the change affect where you go shopping?

I started considering buying items from other places I did not use to go often before [ ]

Section B

I still maintained the usual places where I used to go shopping before

1. Age category

19 years and below [ ] $20-35$ years [ ] 36-50 years [ ] Above 50 years [ ] 
2. Highest educational level

No education [ ] Primary School [ ] Secondary school [ ]

Diplomas/NCE [ ] Graduate [ ] Postgraduate [ ]

3. Occupation/Profession

Unemployed [ ] Students/Apprentice [ ] Pensioners [ ]

Nanny/Housekeeper/Cook/Messenger/Cleaner [ ] Farmer [ ]

Self-employed semi-skilled worker - tailor/hair dresser/driver/security ［ ] Private employees [ ]

Junior Civil servants [ ] Senior civil servants [ ] Senior professionals -Consultants/Professors/Judges etc [ ]

Business owners/administrators [ ] Chief Executive Officers [ ] Top government officials/Diplomats [ ]

4.Monthly Income level: Below $\$ 50,000$ [ ] ] $\$ 51,000$ to $\$ 100,000$ [ ] $\$ 101,000$ to $\$ 200,000$ [ ] $\$ 201,000$ to $\$ 350,000$ [ ] ] $\$ 351,000$ to $\$ 500,000$ [ ] ] Above $\$ 500,000$ [ ]

5. Household/ Family size: 1 -2 persons [ ] $3-5$ persons [ ] 6-8persons [ ] 9 persons and above [ ]

\section{Copyrights}

Copyright for this article is retained by the author(s), with first publication rights granted to the journal.

This is an open-access article distributed under the terms and conditions of the Creative Commons Attribution license (http://creativecommons.org/licenses/by/4.0/) 